\title{
THE EFFECT OF DENATURATION ON THE REACTIVITY BETWEEN THIOL-THIAMINES AND OXIDIZED EGG ALBUMIN ${ }^{1}$
}

\author{
ISAMU UTSUMI, KIYOSHI HARADA AND KEIICHI KOHNO ${ }^{2}$ \\ Osaka Research Laboratory. T'anabe Seiyaku Co., Ltd., Osaka
}

(Received April 1, 1964)

\begin{abstract}
Disulfide groups of proteins are known to have generally a poor reactivity in their native state, but their reactivity increases after heat or urea denaturation $(1,2)$. However, it was reported in the foregoing paper (3), that the -S-Slinkages formed by iodine oxidation of the SH-groups of native egg albumin could react with the thiol-form of thiamine or $O$-benzoylthiamine (OBT) without denaturation. To investigate the effect of denaturation on the reaction is an interesting problem, giving means of elucidating the molecular structure of proteins. Investigation was therefore made of the effects of the denaturation brought about by heating or adding urea after or prior to the iodine oxidation process on the reactivity of the -S-S- group formed by oxidation of $\mathrm{SH}$ groups in egg albumin. The reactivity was evaluated by determining the amounts of the protein-thiamine mixed disulfide produced in the reaction between thiol-type thiamines and the protein. The formation of mixed disulfide was found to be markedly decreased when thiamine was allowed to react with the protein, whose SH groups had been oxidized after being liberated by denaturation. This is a finding which had not been observed thus far. The mechanism is to be settled by manifold researches, but the authors assume at present that the oxidation of the SH-groups to SS-form become difficult because of the increased distance between two SH groups in the denatured protein as a result of unfolding of its $\alpha$-helix configuration.
\end{abstract}

\section{EXPERIMENTAL}

\section{Reaction with the Protein Oxidized after Heat Denaturation}

To $10 \mathrm{ml}$ of $2.5 \%$ egg albumin solution $(250 \mathrm{mg})$ denatured by the method described in the previous paper (4) was added $0.5 \mathrm{ml}$ of $0.1 \mathrm{~N} \mathrm{I}_{2}$-KI solution, and the mixture was kept standing for one hour at $5^{\circ}$. For adjusting the $\mathrm{pH}, 10 \mathrm{ml}$ of each appropriate buffer solution (for $\mathrm{pH} 5$ to $6 \mathrm{Mcll}$ vaine buffer, for $\mathrm{pH} 7$ to 8 $0.3 M$ phosphate buffer, and for $\mathrm{pH} 8$ to 9.2 Clark-Lubs buffer) was added to the oxidized solution. After adjusting the $\mathrm{pH}, 2 \mathrm{ml}$ of thiamine or OBT solution containing the amount equivalent to $2 \mathrm{mg}$ thiamine per $\mathrm{ml}$ of the buffer, was added to the solution and water was filled up to $30 \mathrm{ml}$. The mixture was reacted

\footnotetext{
${ }^{1}$ Studies on Interaction of Thiamine or its Related Compounds with Protein. VI.

2 内海 勇, 原田 清, 河野啓一
} 
at $37^{\circ}$ for one hour.

\section{Reaction with the Protein Urea-denatured after Oxidation}

Ten milliliters of $2.5 \%$ egg albumin solution was oxidized with $0.1 \mathrm{~N}$ iodine solution and the $\mathrm{pH}$ was adjusted to 9.0 or 10.0 with $0.1 \mathrm{~N} \mathrm{NaOH}$ solution. An aliquot of urea ( 2 to $10 \mathrm{~g}$ ) was then added to the solution and the mixture was kept standing at $5^{\circ}$ for 30 minutes, $10 \mathrm{ml}$ of Clark-Lubs buffer solution $(\mathrm{pH} 9.0$ or 10.0) and $2 \mathrm{ml}$ of thiamine or OBT solution containing the amount corresponding to $10 \mathrm{mg}$ of thiamine were added and water was filled up to $30 \mathrm{ml}$. The mixture was further allowed to react.

\section{Reaction with the Protein Oxidized after Urea Denaturation}

An aliquot of urea was added to $10 \mathrm{ml}$ of $2.5 \%$ egg albumin solution and the mixture was kept standing at $5^{\circ}$ for 30 minutes. $0.3 \mathrm{ml}$ of $0.1 \mathrm{~N}$ iodine solution was then added, and the whole was kept standing at the same temperature for one hour. The solutions were adjusted to $\mathrm{pH} 9.0$ or 10.0 by adding $0.1 \mathrm{~N}$ $\mathrm{NaOH}$ solution and $10 \mathrm{ml}$ of the buffer solution and were allowed to react with $10 \mathrm{mg}$ of thiamine or OBT (equivalent to thiamine.)

4. Reaction of Urea-denatured Protein with Thiamine Disulfide Derivatives

An aliquot of urea was added to $10 \mathrm{ml}$ of $2.5 \%$ egg albumin solution for denaturation. To the mixture were added $6 \mathrm{ml}$ of $0.5 M$ phosphate buffer ( $\mathrm{pH}$ 7.3) and thiamine disulfide (TDS) or $O$-benzoylthiamine disulfide (BTDS) in the amount equivalent to $10 \mathrm{mg}$ thiamine in the total volume of $30 \mathrm{ml}$. The mixture was kept standing at $37^{\circ}$ for one hour. The percentage reaction was calculated by determining the amount of free and bound thiamine.

\section{Determination of Bound Thiamine}

Bound thiamine was determined by the method described previously (5), i.e., the protein fraction obtained by precipitation with metaphoshoric acid was treated with sodium thiosulfate and the free thiamine thus liberated was estimated by the thiochrome method.

\section{RESULTS}

\section{Effect of Heat Denaturation}

Comparison was made at various $\mathrm{pH}$ levels between the interaction of thiamine or OBT with iodine-oxidized egg albumin whose SH-groups had been liberated by heat denaturation and that with directly oxidized egg albumin without denaturation. As can be seen from the result shown in Fig. 1, no significant difference in the reactivity was detectable at $\mathrm{pH} 5$ to 7 were the concentration of thiol-type thiamine (or OBT) is low. However, at $\mathrm{pH}$ levels above 8.0, where reactivity rises rapidly, the formation of bound thiamine or OBT was markedly decreased by heat denaturation prior to oxidation. That the SH-groups of egg albumin become markedly more reactive by heat denaturation was shown by the reactivity with disulfide type thiamine as TDS and BTDS (4). However, in the case of the protein oxidized with iodine, the -S-S- linkage produced from the $\mathrm{SH}$ groups of heat-denatured albumin, appears to be less reactive than that produced from native albumin. 


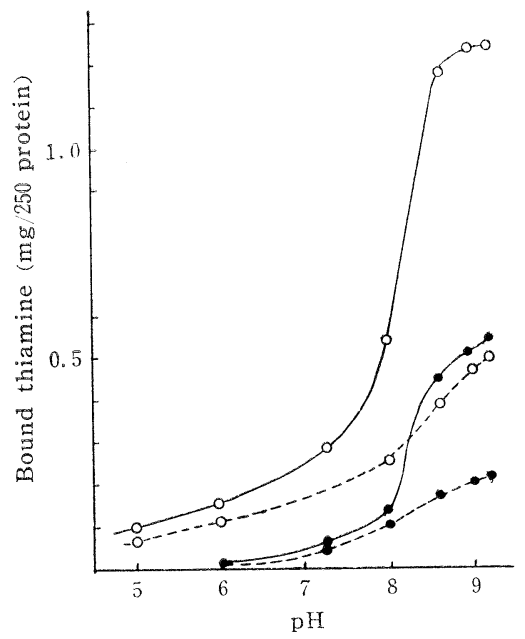

FIG. 1 Heat Denaturation and Reactivity

, thiamine; $\mathrm{O}, \mathrm{OBT}$

$\longrightarrow$, native $\rightarrow$ oxidized ; ......, denatured $\rightarrow$ oxidized.

\section{Effect of Urea Denaturation}

The denaturation by urea is not so severe as that by heat, and the denaturation can proceed mildly by adjusting the amount of urea. So the effects of varying degrees of denaturation were therefore studied as follows. To $10 \mathrm{ml}$ of $2.5 \%$ egg albumin solution were added various amounts of urea in the range of 2 to $10 \mathrm{~g}$. The albumin solution had been either oxidized after denaturation or denatured after oxidation. Using the solutions thus treated, the reaction with thiamine or OBT was observed at $\mathrm{pH} 9.0$ or 10.0. The amount of thiamine bound with protein in each case was given in Table 1. and the percentage

TABLE I

Denaturation and Reactivity

\begin{tabular}{|c|c|c|c|c|c|c|c|}
\hline \multirow{2}{*}{$\begin{array}{l}\text { Treatment of } \\
\text { protein }\end{array}$} & \multirow{2}{*}{$\begin{array}{l}\text { Thiamine } \\
\text { derivative }\end{array}$} & \multirow{2}{*}{$\mathrm{pH}$} & \multicolumn{5}{|c|}{$\begin{array}{l}\text { Amount of urea added } \\
(\mathrm{g} / 250 \mathrm{mg} \text { protein })\end{array}$} \\
\hline & & & 0 & 2 & 4 & 6 & 10 \\
\hline \multirow{3}{*}{$\begin{array}{l}\text { Oxidized } \\
\longrightarrow \text { denatured }\end{array}$} & & & & $\begin{array}{l}\text { nount o } \\
g / 250 m g\end{array}$ & protein & ne bou & \\
\hline & Thiamine & $\begin{array}{r}9.0 \\
10.0\end{array}$ & $\begin{array}{l}690 \\
680\end{array}$ & $\begin{array}{l}680 \\
640\end{array}$ & $\begin{array}{l}685 \\
645\end{array}$ & $\begin{array}{l}690 \\
605\end{array}$ & $\begin{array}{l}680 \\
540\end{array}$ \\
\hline & OBT & $\begin{array}{r}9.0 \\
10.0\end{array}$ & $\begin{array}{l}1,500 \\
1,450\end{array}$ & $\begin{array}{l}1,320 \\
1,280\end{array}$ & $\begin{array}{l}1,200 \\
1,240\end{array}$ & $\begin{array}{l}1,140 \\
1,140\end{array}$ & $\begin{array}{l}1,020 \\
1,860\end{array}$ \\
\hline \multirow[t]{2}{*}{$\begin{array}{l}\text { Denatured } \\
\longrightarrow \text { oxidized }\end{array}$} & Thiamine & $\begin{array}{r}9.0 \\
10.0\end{array}$ & $\begin{array}{l}690 \\
680\end{array}$ & $\begin{array}{l}655 \\
385\end{array}$ & $\begin{array}{l}490 \\
225\end{array}$ & $\begin{array}{l}295 \\
220\end{array}$ & $\begin{array}{l}245 \\
230\end{array}$ \\
\hline & OBT & $\begin{array}{r}9.0 \\
10.0\end{array}$ & $\begin{array}{l}1,500 \\
1,450\end{array}$ & $\begin{array}{r}1,280 \\
770\end{array}$ & $\begin{array}{l}840 \\
500\end{array}$ & $\begin{array}{l}650 \\
500\end{array}$ & $\begin{array}{l}480 \\
440\end{array}$ \\
\hline
\end{tabular}

combination was summarized in Figs. 2 and 3, whereby the amout of the vitamin bound with native protein directly oxidized was taken as 100 . When the protein was denatured after oxidation, the amount of the protein-bound thiamine or OBT 


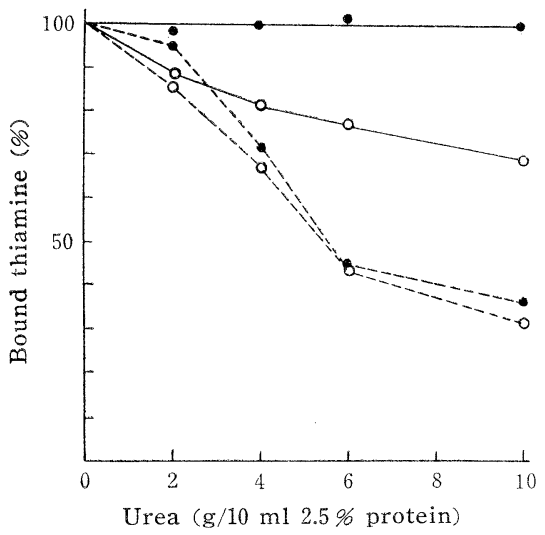

FIG. 2 Urea Denaturation and Reactivity at $p H 9.0$

The amount bound with non-denatured protein was taken as 100

- thiamine; 0 , OBT

$\longrightarrow$, oxidized $\rightarrow$ denatured ; ......., denatured $\rightarrow$ oxidized.

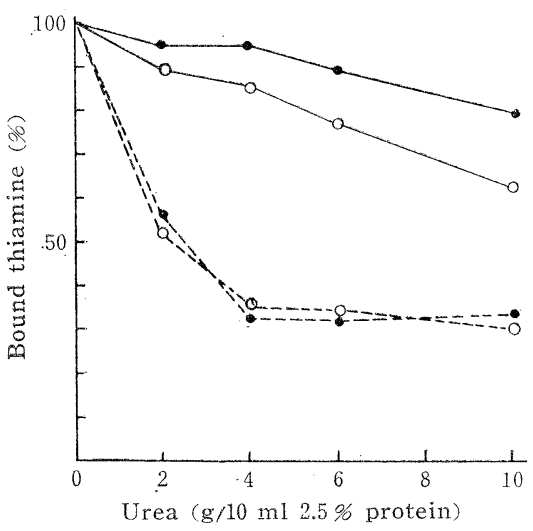

Fig. 3 Urea Denaturation and Reactivity at pH 10.0

The amount bound with non-denatured protein was taken as 100

- thiamine; $0, \mathrm{OBT}$

$\longrightarrow$, oxidized $\rightarrow$ denatured ; -....-., denatured $\rightarrow$ oxidized

was somewhat decreased, but when the protein was oxidized after denaturation, the amount of the bound thiamine was markedly decreased, as was the case with heat denaturation, and the decrease was more marked with the degree of denaturation. When this finding was compared with that (Fig. 4) of the reaction

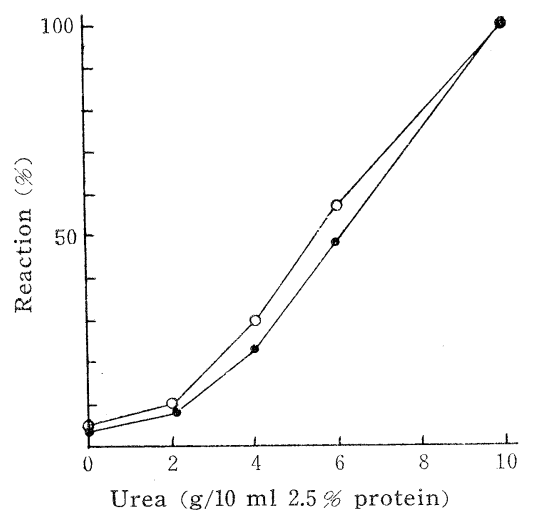

FIG. 4 Reaction of Thiamine Disulfide Derivatives with Urea-denatured Protein The amount reacted with the protein denatured with $10 \mathrm{~g}$ of urea was taken as 100 .

- TDS; 0, BTDS

of the SH groups of urea-denatured egg albumin with disulfide-type thiamine derivatives (production of free and bound thiamine), the results were entirely opposite. That the reactivity of the SH-groups of protein increases with the degree of denaturation is clear from the reaction with the disulfide-type thiamine, but the reactivity of the -S-S-groups of the oxidized protein with the thiol forms 
of thiamine derivatives was decreased with the degree of denaturation, a finding which seems contradictory. When $250 \mathrm{mg}$ of native egg albumin was oxidized at $5^{\circ}$ for 60 minutes, the amount of $0.1 \mathrm{~N}$ iodine consumed at $\mathrm{pH} 7.0$ was less than $0.3 \mathrm{ml}$ and the amount of bound thiamine showed a maximum value at nearly $0.3 \mathrm{ml}$. The consumed amount of the iodine solution was increased by about $0.5 \mathrm{ml}$ when the urea-denatured albumin was used. In this case the amount of the iodine solution was further raised to 0.4 to $0.6 \mathrm{ml}$, but the bound amount remained constant, showing that the decrease in the reactivity is not due to the deficiency of iodine.

\section{DISCUSSION}

It was found that the reactivity of the -S-S-group of the egg albumin produced by oxidation with iodine after denaturation of the native form was markedly lower than that produced by direct oxidation, a finding which has hitherto been unknown and seems to raise an interesting problem for solving the activated state of the SH groups of protein by denaturation and its oxidation mechanism as well as the molecular structure. For the formation of protein-thiamine-mixed disulfide by the reaction of the thiol-forms of thiamine derivatives with oxidized protein, it seems necessary that the SH-groups of the protein are preliminarily oxidized to -S-S-groups. The apparent decrease in the reactivity of the -S-S-groups of the protein seems to be due to the decreased formation of the intramolecular -S-Slinkages itself which are involved in the reaction. Anson et al. (6) reported that the SH-groups of egg albumin form intramolecular -S-S-linkages by iodine oxida tion rather than intermolecular -S-S-linkages, so that two SH-groups may be oxidized to -S-S- form. They are considered to be situated adjacently in protein molecule (7). Taking these assumptions into consideration, the unfolding of the intramolecular polypeptide chain of the protein molecule as a result of denaturation may result in the greater distance between the SH-groups of the protein molecule which makes the formation of intramolecular -S-S-linkages difficult. If the liberated SH-groups of the protein can hardly be oxidized to the intermolecular -S-S-linkages, they may be oxidized to $-\mathrm{SO}_{2} \mathrm{H}$ or $-\mathrm{SO}_{3} \mathrm{H}$ as in the case with iodine oxidation of cysteine (9). Huggins et al. (10) and many others have reported that $\mathrm{SH}$ and -S-S- groups in protein cause an exchange reaction by denaturation, producing intermolecular -S-S- linkage. In such case, formation of intramolecular -S-S- linkage by iodine oxidation may be reduced, because of the decrease of adjacent SH-groups. It was stated with some examples that the SH groups of protein could not always be converted to -S-S- form by oxidation $(7,8)$.

That the similar conclusion was deduced from the reaction with thiamine thiols, is of interest and may suggest the potential usefulness of this reaction for a means in protein chemistry, though it remains to be studied in details.

It is also an interesting finding that the S-S-linkages produced by iodine oxidation of the SH-groups of the native protein showed a marked reactivity with the thiol forms of thiamine derivatives and the -S-S-linkages thus formed did not show any increase in reactivity by denaturation. The -S-S-linkages seem to become reactive by the removal of steric hindrance by some reasons when the -S-S- 
linkages were formed by oxidation. Although no significant difference in optical rotatory dispersion of the protein was observed ${ }^{3}$ befere and after the oxidation, a possible removal of hydrogen bonds at $\mathrm{SH}$-groups, or an iodination of tyrosine residue may serve for a local unfolding of the $\alpha$-helix configuration. Potassium iodine (11) which is known to be a denaturing agent for egg albumin was contained in $0.1 \mathrm{~N}$ iodine solution used for oxidation, but the amount was too small to be evaluated. The observation of the interaction of thiamine derivatives with protein may be useful for investigating their behavior in vivo.

\section{SUMMARY}

Egg albumin oxidized with iodine reacts with the thiol form of thiamine or $O$ benzoylthiamine (OBT), forming a protein-thiamine mixed disulfide. The amount of the disulfide formation was markedly decreased by heat or urea denaturation before oxidation. The reactivity was greatest, when the SH-groups of the native protein was oxidized directly. Denaturation after oxidation did not cause any significant change in reactivity. When the SH-groups of the native protein was oxidized after denaturation, the reactivity was lowered with the degree of denaturation. The finding seems to be due to the decreased formation of the intramolecular -S-S-linkages in the protein molecule which are involved in the reaction with the thiol forms of thiamine derivatives owing to the denaturation prior to oxidation.

\section{ACKNOWLEDGEMENT}

The authors wish to express their grateful thanks to Dr. Masao Fujisawa and Dr. Norio Sugimoto of our Company for their constant encouragement.

\section{REFERENCE}

1. Walker, E., Biochem. J. 19, 1082, (1925).

2. Kolthoff, I.M., Anastasi, A., Stricks, W., Tan, B.H. and Deshmukh, G.S., J. Am. Chem. Soc. 79, 5102, (1957); 80, 3235, (1958).

3. Utsumi, I., Harada, K., Kohno, K., and Hirao, H., J. Vitaminol 10, 1 (1964).

4. Utsumi, I., Harada, K. and Kohno, K., ibid. 9, 41 (1963).

5. Utsumi, I., Harada, K., Kohno, K. and Hirao, H., ibid. 9, 50 (1963).

6. Anson, M. L., J. Gen. Physiol. 25, 355 (1942).

7. Chinard, F. P. and Hellerman, L., Methods of Biochemical Analysis 1, 1, Interscience Publishers (1954).

8. Cecil, R. and McPhee., Advance in Protein Chemistry 14, 25, Academic Press (1959).

9. Shinohara, K., J. Biol. Chem. 96, 285 (1932).

10. Huggins, C., Tapley, D. F. and Jensen, E. V., Nature 167, 592 (1951).

11. Greenstein, J. P., J. Biol. Chem. 130, 519 (1939).

\footnotetext{
${ }^{3}$ Utsumi et al. unpublished.
} 